NBER WORKING PAPER SERIES

WHY IS PRODUCTIVITY GROWING FASTER?

Martin Feldstein

Working Paper 9530

http://www.nber.org/papers/w9530

\author{
NATIONAL BUREAU OF ECONOMIC RESEARCH \\ 1050 Massachusetts Avenue \\ Cambridge, MA 02138 \\ February 2003
}

The views expressed herein are those of the author and not necessarily those of the National Bureau of Economic Research.

(C)2003 by Martin Feldstein. All rights reserved. Short sections of text not to exceed two paragraphs, may be quoted without explicit permission provided that full credit including Cnotice, is given to the source. 
Why is Productivity Growing Faster?

Martin Feldstein

NBER Working Paper No. 9530

February 2003

JEL No. E0

\begin{abstract}
Productivity in the United States has been growing faster in the past seven years than it did in the previous quarter century. U.S. productivity growth accelerated while that in Europe declined. This paper asks why U.S. productivity growth has been faster than in the past and than in Europe.
\end{abstract}

An important reason for the faster growth has been the strong incentives for managers at all levels to make the kinds of changes that can raise productivity even if that involves personal risk and discomfort. These incentives became much stronger during the 1990s for reasons that I speculate about but do not begin to understand fully.

The information technology developments in personal computers and in internet and intranet communications provided a powerful means to achieve the productivity gains that everyone was seeking. But even if the new IT opportunities had not come along, the combination of strong incentives and a receptive corporate climate would have led managers to find other ways to increase productivity, although undoubtedly not by as much.

European firms had neither the incentive structure nor the corporate environment supportive of making change that could involve significant job changes and layoffs. Although Europe has higher unemployment rates, it is much more difficult to lay off workers in Europe than in the United States. Reorganizing white collar work to change job assignments and locations is also much easier in the U.S. than in Europe.

The future is likely to see continued strong productivity growth and perhaps even increasing productivity growth in the United States if the incentives and corporate environments remain supportive. The prospects for Europe remain uncertain.

Martin Feldstein

National Bureau of Economic Research

1050 Massachusetts Avenue

Cambridge, MA 02138

feldstein@nber.org 


\title{
Why is Productivity Growing Faster?
}

\author{
Martin Feldstein*
}

The rise in the growth rate of productivity has been the key economic fact in the U.S. economy during the past decade. Faster productivity growth has raised the growth rate of real incomes, kept inflation under control even though the tightening labor markets since 1995 have caused wage increases to accelerate, and dampened the magnitude of the output decline in the recession that began in early 2001.

It is important to understand why productivity has grown so rapidly in order to assess what is likely to happen in the future and what can be done to maintain or even increase the rate of productivity growth.

My conclusion is that the acceleration of productivity that began in the mid-1990s reflects more than just the availability of new information technology, the most commonly cited explanation. Incentives and institutional structures were critical ingredients in the rise of productivity. Without strong incentives and appropriate institutional structures, the developments in information technology would not have been transformed into faster productivity growth.

\section{$\underline{\text { Some Stylized Facts }}$}

Let me begin with some stylized facts that characterize the faster growth of productivity. Between 1970 and 1995, productivity in the non-farm business sector rose at an average annual rate of 1.6 percent. In the seven years since then, the rate of increase was 2.6 percent.

There is no sign that the rate of productivity growth is slowing down. In the year ending

*Professor of Economics, Harvard University, and President of the National Bureau of Economic Research. This paper was presented at the American Economic Association session on The New Economy and Growth in the United States, January 3, 2003. 
with the third quarter of 2002 productivity rose 5.8 percent. This no doubt reflects the productivity pick-up as output rose from the very weak economy at the end of 2001. But even if we look back before the recession to the period beginning in the third quarter of 2000 , the two year productivity growth since then has averaged 3.1 percent.

Before going further, I should stress the need for caution in interpreting such productivity statistics. Much of the measured change in productivity reflects estimated improvements in product quality rather than increases in the number of physical units of output. In a time of low inflation, these quality improvements often appear as estimated decreases in the real prices of the products. Consider the improvements in computers, a major component of the productivity change. How confident can we be of the measure of this change when the official annual rates of change of the real price of computers and peripherals has varied since 1995 between minus 20 percent a year and minus 35 percent a year. The uncertainty of these measures should be born in mind in interpreting what I will say as well as in interpreting studies that try to be more precise than my impressionistic comments.

An important feature of the productivity surge of the past seven years is that it has not occurred in Europe or in Japan. The productivity rise there has been less since 1995 than it was in earlier years. And while the U.S. productivity rise has been accompanied by a substantial increase in employment, the volume of employment in Europe has stagnated. Looking ahead, the European Commission's recent Economic Review predicts that the annual growth rate in Europe during the next fifty years will be only half that in the United States. ${ }^{1}$ So the title of my

${ }^{1}$ Some of this difference in growth rates is of course due to a lower rate of growth of population in the EU countries than in the United States. 
talk, "Why is Productivity Growing Faster?", can be interpreted as "faster in the U.S. than elsewhere" as well as "faster now than in the previous quarter century."

The increase in business investment was a contributory factor but cannot by itself explain the faster productivity rise. Moreover, the investment rate is endogenous and may have been, at least in part, a response to the increased rates of return on investments made possible by the new information technology. It may also have been a reaction to the changed management incentives about which I will comment in a moment.

Careful studies by several researchers have established that the productivity growth rate was particularly strong in those parts of the economy where information technology goods are produced. ${ }^{2}$ I believe this primarily reflects the product improvements rather than changes in the manufacturing process itself. In that part of the economy, not surprisingly, the European productivity gains were almost as large as those in the United States.

The big difference in the productivity increase between the U.S. and Europe has been in the sectors that are substantial users of IT equipment and software. In the US, the industries that used IT intensively saw very substantial gains in productivity while in Europe there was no increases in the rate of productivity gain. US productivity growth also rose in those industries that did not use IT , although the gains were smaller. Again, Europe did not have equally strong productivity gains in those industries.

${ }^{2}$ See, for example, Robert Gordon, "High Tech Innovation and Productivity Growth: Does Supply Create Its Own Demand?”, NBER Working Paper, 2003 (www.nber.org/papers) and Bart van Ark et. al. "Change Gears: Productivity, ICT and Services: Europe and the United States," Groningen Growth and Development Centre Working Paper GD-60, 2002 (www.eco.run.nl/ggdc/pub/gd60.shtml) van Ark estimates that productivity in the ICT (information and communication technology) industries rose at an annual rate of more than 10 percent from 1995-2000 and at more than 23 percent in the ICT manufacturing industries. 


\section{The New Technology}

Current generation computers, the internet, and high speed connections are now so much a part of all of our daily lives that it is easy to forget how much has changed in the past few years. Since the mid-1990s, when productivity growth accelerated, there have been fundamental changes in all aspects of the information technology used in business as well as in research and in our personal lives.

Desk top computers have become faster and more user friendly, thanks to Windows and improvements in a variety of standard office software packages. The new computers and software can change the way that everyone in an organization works and communicates. Company data systems allow managements to accumulate and process vast amounts of information on a timely basis.

The use of the internet and corporate intranets not only makes individuals more productive as they search and process information but also permits significant reductions in staff levels as managers can deal directly with much larger numbers of individuals and communicate throughout the organization without the help of lower level managers and other support staff. The internet and intranet have changed supply chain management, product design and development, and inventory management.

It is, as we all know from our own experience, a very different world than it was just a few years ago. I see this every day not only in my own personal work but in the operation of the NBER where a smaller support staff can now manage a much larger and more complex organization, and can share data and research results with thousands of users around the world every day. 
The productivity gains made possible by the new information technology have been concentrated in white collar jobs. While earlier generations of technological change permitted automation and robots in the production process, the IT revolution has brought productivity gains to management, sales, purchasing, design, accounting and other non-production activities. This is, in fact, where most of the jobs are now, even in the manufacturing industry.

When we think about the dramatic changes in technology that have occurred, it is perhaps surprising that the rate of productivity increase has risen by only about one percent a year, implying that an organization with 100 employees can reduce its staff by only one additional person per year while producing the same level of output. Over the past seven years, the increased productivity has been equivalent to a 7 percent rise in output or a 7 percent fall in the staff needed to do the original level of work. My casual empiricism tells me that there is a lot more to come as firms learn to use the new technology and the new software and to make the organizational changes that allow more output or reduced staff inputs. Even if there were no future advances in computer technology and communications and in the standard programs to be used with that technology - all an unlikely assumption - new gains could come from developing company-specific software and from modifying the management software systems like SAP to specific company needs.

\section{The Speed of Adopting the New Technology}

This brings me to the questions of what determines the speed with which the new technology is being adopted and why we saw these gains in the United States but not in Europe. Much research needs to be done to answer those questions, particularly microeconomic research 
on the experience in different firms and narrowly defined industries. ${ }^{3}$ For now I can only speculate. $^{4}$

Innovation is disruptive and costly. Innovation is also risky, since the new system may not work well after it is put in place. Output may decline during the transition while people are learning to use the new system. Innovation is often frightening to the people who have to learn new systems, particularly older workers for whom new computer technology may never be userfriendly enough. Innovation can also be personally unpleasant for managers if it involves forcing unwanted personnel changes and mandatory early retirements.

The business process innovations nevertheless occurred in U.S. firms because the general environment supported and encouraged change while the individuals who made the decisions to drive change had strong incentives to do so. Both aspects were much more favorable to change in the United States than in Europe. And while much of the change was associated with the new information technology, the heightened incentives induced a faster pace of change in other aspects of management and production as well.

The nature of compensation changed substantially in the American companies in the 1990s. Bonuses and equity-based compensation (shares and options) became much more important relative to ordinary salary, not only for top managers but throughout companies. There has been much recent attention to some egregious examples of overcompensation that

${ }^{3} \mathrm{~A}$ substantial new project to study these issues with micro data and first-hand observations is now getting started at the NBER under the direction of Richard Freeman and Kathryn Shaw.

${ }^{4}$ My earlier comments on this subject were published in "The Productivity Divide," The Financial Times, June 28, 2001 [http://www.nber.org/feldstein/ft062801.html] 
resulted from option plans and of the dishonest reporting of company incomes that was induced in part by these new forms of compensation. But the increase in incentive compensation, tied to individual and company performance, also caused executives and lower level managers to take risks, to work harder, and to engage in the unpleasant tasks that raised productivity. These changes in behavior were a response not only to the carrots of incentive compensation but also to the sticks of employment termination and other pressures on each level of management from those above them.

The basic reasons for these changes in compensation are not well established. In part, boards of directors and top executives were responding to the pressure from investment managers and Wall Street analysts to "create shareholder value," i.e., to raise profits. Much of this may in turn have reflected the increasing professionalization of portfolio managers who were to an ever greater extent working for corporate pension funds where performance was judged on a quarterly basis. The emphasis on management performance and payment for creating shareholder value may also reflect the ascendency of a new type of manager who had been trained in a business school to quantify goals and performance.

Raising profits and creating shareholder value was often equivalent to reducing costs. Some firms attributed this focus on cost reduction to the reduced market power of companies to raise prices because they faced competition not only from other domestic firms but from increasingly sophisticated producers around the world. The low general rate of inflation was accompanied by very low or even negative rates of price change for goods at the level of the producer.

The situation in Europe was quite different. Incentive compensation in general and the 
use of stock options in particular is generally much less significant in Europe than in the United States. With a few notable exceptions, the idea of increasing shareholder value was not central to managements' goals. Much more weight was given in both rhetoric and practice to achieving satisfactory performance for all of the so-called "stakeholders" including all employees, customers, and the government. This may play a large part in explaining why the adoption of IT has occurred at a substantially slower pace in Europe than in the United States. ${ }^{5}$

Even if the technical changes in information technology had not occurred, the pressures to raise profits and reduce costs would have led to a greater increase in productivity in the United States. Information technology was just the means, a very powerful means, for translating the pressure for profit enhancement through cost reduction into practice. Notions of radically reengineering the corporation ${ }^{6}$ to raise productivity were an emphasis of American managers even before the IT revolution began.

The US-Europe difference is not just a matter of incentives. The organizational rules and constraints are also very different on the two sides of the Atlantic ocean. European work rules, embodied in union agreements and legislation, make it much more difficult to change work assignments or discharge redundant workers. And to the extent that is true, it acts as a barrier and a disincentive. Why introduce a new technology that permits managing with fewer employees when you cannot discharge those who become redundant? And even when changing work assignments can eventually be achieved, the effort to do so is so great that in many cases European managers are discouraged from even starting.

\footnotetext{
${ }^{5}$ See van Ark e. al., op. cit., for evidence on the slower adoption of IT in most of Europe.

${ }^{6}$ Michael Hammer and James Champy Reengineering the Corporation (1994) 
The same combination of differences in incentives and in institutional constraints may also explain much of the US-EU difference in productivity gains in retailing, one of the key sectors contributing to the difference between US and EU productivity gains (according to van Ark et al 2002). European limits on the number of shopping hours per week and restrictions on building reduce the incentive for the capital accumulation that raises productivity in this sector. Of course, measuring productivity change in retailing is particularly difficult because the mix of service quality, self-service requirements, and consumer time have changed without being adequately reflected in measuring the output of retail services.

The Future

I recognize that much of what I have said is based on personal impressions rather than the kind of detailed evidence that I hope will eventually be produced. But I would nevertheless draw the following tentative conclusions:

Productivity in the United States is growing faster because there have been strong incentives for managers at all levels to make the kinds of changes that can raise productivity even if that involves personal risk and discomfort.

These incentives became much stronger during the 1990s for reasons that I have speculated about but do not begin to understand fully.

In addition to personal incentives from a revised compensation structure, individual managers were influenced by a corporate environment that emphasized and permitted driving down costs to create shareholder value.

The information technology developments in personal computers and in internet and intranet communications provided a powerful means to achieve the productivity gains that 
everyone was seeking. But even if the new IT opportunities had not come along, the combination of strong incentives and a receptive corporate climate would have led managers to find other ways to increase productivity, although undoubtedly not by as much.

European firms had neither the incentive structure nor the corporate environment supportive of making change that could involve significant job changes and layoffs. Although Europe has higher unemployment rates, it is much more difficult to lay off workers in Europe than in the United States. Reorganizing white collar work to change job assignments and locations is also much easier in the U.S. than in Europe.

The future is likely to see continued strong productivity growth and perhaps even increasing productivity growth in the United States if the incentives and corporate environments remain supportive. The prospects for Europe remain uncertain.

Cambridge MA

December 2002 